\title{
Research on the New and Innovative Pattern of College Students' Ideological and Political Education under the Guidance and Perspective of the Core Values Theory
}

\author{
Shuyun Ruan ${ }^{1}$ \\ ${ }^{1}$ Guangxi Eco-engineering Vocational and Technical College, \\ Liuzhou, Guangxi 545004 China
}

\begin{abstract}
In this paper, we conduct in-depth research on the new and innovative pattern of college students' ideological and political education under the guidance and perspective of the core values theory. Implementation of ideological and political theory course construction will perfect the theory of education system. The dominance of socialist core values embodied in the noble moral and value pursuit of the process, it plays a major guiding role. Universities should give full play to the important role of ideological and political theory and adhere to Marxist theory as a guide and fully carry out the socialist core values education which will hold special meaning for students.
\end{abstract}

Keywords: Ideological and Political Education; Core Values Theory; Innovative Pattern.

\section{Introduction}

As the basis of socialist core value system is the most core part of the socialist core values can be reflected the value of China's harmonious society pursues scale and cultural concept. Since the eighteenth congress, the central attaches great importance to cultivate and practice the socialist core values. The president general secretary made important paper which put forward clear requirements for many times, the central committee attaches great importance to and strongly deployment, in order to strengthen the socialist core values education practice pointed out the direction, provides important follow. In today's diverse values, cultural diversity during the period of social transformation, in the young college students unequivocally advocate socialist core values, to deeper influence young students' way of thinking and behavior which will improve the actual effect of ideological and political education. Contemporary college students' thought condition determines the colleges and universities must adhere to the socialist core values guide the ideological and political education. Overall, the mainstream of the modern college students is positive and healthy, but some students have some negative thoughts, and seriously restrict the healthy growth [1].

College students are in a critical period of values forming is not yet mature. In the face of diversified culture, lose the ability to identify and judgment ability, easy to be fooled by "sugar-coated cannonball", in addition some bad social ethos into the campus, the college students' ideology and value orientation has certain negative influence. In addition, the new rapid development of information technology, especially Internet has enriched people's life, study, work, became the most popular of today's media. College students in content and its rich network culture has a strong curiosity, identify, poor ability of self-control is not strong, vulnerable to the influence of all kinds of bad information. At present, the college students have become a major source of Internet users.

The Internet has become the main carrier of information dissemination, has become today's college students meet the requirements of their own development and with the quickest speed to get all the latest information resources of main channel, but the network for college students' work, study and life bring about negative 
impacts. The core content of the ideological and political education is the cultivation and training of core socialist values. Non-computer majors on campus, to transform the traditional ideological and political education of college students' education idea, through the use of the socialist core values of some typical cases of interpretation, in terms of flexible guide to improve college students' ideological and political education of targeted. Socialist core values is the kernel of the system of socialist core values, reflect the radical nature of the socialist core value system and the basic characteristics, reflects the rich connotation of the socialist core value system and practical requirements, is the height of the socialist core value system of concise and concentrated expression.

On the socialist core values guide the ideological and political education significance could be summarized as the follows. (1) The inevitable choice to promote and enhance the college students' all round development. Because of the wet behind the ears, the lack of political experience and the actual exercise, they think of many social problems are often simple, one-sided. Does not yet have mature mental quality and bear ability, psychological adjustment ability is not strong, once the problems in study, life, easy to cause psychological unbalance. (2) Under the new situation of ideological and political education content innovation of reality. College students' ideological and political education content should keep pace with The Times, The Times. Both must be stable and the continuity of the content, and to follow the time development thought college students themselves and the actual development. Practice has proved that using the latest achievements in adapting Marxism to Chinese education students, the ideological and political education is to realize the innovation of the key. Therefore, colleges and universities should take opportunities, concentrated force which becomes the pioneers of the socialist core values education study. (3)
The urgent need of ideological struggle. Every social system or the same social system under the different development period, there are corresponding core values. A country and a society without the core values of most people, then it will be difficult to form a unified the country society of spiritual power, will lose cohesion and combat effectiveness and it cannot be rapid, healthy and sustainable development [2].

In this paper, we conduct in-depth research on the new and innovative pattern of college students' ideological and political education under the guidance and perspective of the core values theory. In ideological education for college students to carry out the socialist core value system, the implementation to the system of socialist core values to shape the values of college students, lead thought trend. In the following sub-sections, we will discuss the issues in detail.

\section{Our Proposed Approach and Method}

The College Students' Ideological and
Political Education. Implementation of ideological and political theory course construction, perfect the theory of education system. Higher school ideological and political theory course is the main channel of moral education in colleges and universities work. Ideological and political theory course is a compulsory course for college students, is to help students establish correct world outlook, the outlook on life, the values of important way, embodies the essential requirement of socialist university. School further implement the central about strengthening and improving ideological and political theory course, advancing with The times, to strengthen the discipline construction as the leading, constantly optimize the curriculum system construction, strengthen the construction of teaching staff and teaching materials, reform teaching methods, improve the theoretical system of education. Students in some lag and pertinence is not strong in the process of ideological and political education, 
and is often difficult to feel the value of ideological and political education and produce alienation, lack of interest in theory and is unwilling to accept, even the effectiveness of ideological and political education [3].

But some students due to the lack of theory armed and often a cry of doubts and confusion, tries to solve the mental confusion in the spontaneous, show the mental state of hunger. This is the current the contradiction between need and supply of ideological and political education of university students which is the ideological and political education must face the problem. Therefore, the ideological and political education should be the humanistic approach to reflect education the text of the concept of development, reform the students from the actual social development and the tendency of actual, really makes it the survival and the development condition of students. Only in this way can the main channel of ideological and political education, to play a leading role to practical.

It is the main task of the ideological and political education of ideal and faith education as the core, to set up the correct world outlook, the outlook on life and values education with emphasis on the patriotic education, to carry forward and cultivate the national spirit education. Since the founding of new China, the ideological and political theory course has a rapid development, play a role of main channel of the ideological and political education. Early since the founding of new China, the ideological and political theory course is mainly engaged in the new democratic transition. At this point, the main task of the ideological and political education more scientific, more comprehensive, holistic and systemic, ideological and political education for college students to largely put forward the general requirements, points the way forward.

Perspective of the Core Values Theory. Values as a kind of social consciousness, reflects the social economy, politics, culture, represent the people to the overall understanding of social life, the basic concept and ideal pursuit. Core values is the concentrated reflection of certain social form social nature, in a leading position in the system of social ideology, determines the basic principle of social system, social, restricts the basic direction of social development. Any society in certain historical stage of development, will be formed that can meet the needs of its basic system and requirements, leading all the value system of social thought and behavior and condensation of these core values. College has important significance for the growth of the youth to become a useful, is often a person world outlook, the outlook on life, values formation of the critical period, it also has an important role in the development of one's life. The importance of correct understanding of socialist core values, consciously cultivate students actively explore and practice the socialist core values of innovation path, is the current ideological and political education work forward development request inevitably.

Bright core values reflect a social dominant value standards, as well as the value of the pursuit of the ideal, can integrate various stakeholders and the maximum behavior main body's enthusiasm, initiative and creativity, play together the role of the united struggle for the realization of broad ideal, is the national development, national progress, loneliness is the spiritual pillar of the missing. Throughout history and reality, in among the nations of the world has a place, must be on the ideology and culture internally with a strong penetration, charisma, strong radiation and influence with the outside world. In view of the college students' ideological dynamic, also in the community to carry out the practice, is one of the important measures to cooperate with classroom teaching practice of core values. College students' socialist core values is the concrete embodiment of socialist core values in college students groups, are college students all values in the decisive role, the nature of the value of the kernel. The main content of 
ideological and political education in the new period is the socialist core value system as the central task of education content new system contains Marxism theory education, the common ideal of socialism with Chinese characteristics, education, national spirit education and the education on socialist concept of honor and disgrace with the spirit of the time.

Values are objective things for people on the basis of cognition, understanding the general view and basic evaluation. Party's eighteen big report of socialist core values made clear instructions, is our party is another important achievement of theoretical innovation. The report stresses that the party's conference points out that: "advocating prosperous, strong, democratic, civilized and harmonious, advocating freedom, equality, justice, rule of law, advocating patriotic, dedicated, sincere, friendly, actively cultivate and practice the socialist core values." This paper focuses on the basic content of socialist core values and core connotation which is the vivid expression of the socialist core values, representing the reflect the will of the people is generally the greatest common divisor, has a strong influence and charisma. Socialist core values embodies the state, society, individual three levels of requirements, these three levels is both independent and interrelated, formed a scientific and unified whole. The significance of socialist core values to student's growth. Cultivating and practicing the socialist core values is to comprehensively deepen reform, promote the construction of socialist modernization with Chinese characteristics to continue the objective needs and internal requirement of developing, and promote the cultural construction of the Chinese nation to realize the great rejuvenation of the Chinese nation the only way for the Chinese dream.

The Core Values Guided Ideological and Political Education. The dominance of socialist core values embodied in the noble moral and value pursuit of the process, it plays a major guiding role. The function of the path of the core values guide the ideological and political education could be separated into the following aspects. (1) Lead the campus harmonious culture construction. Due to the emergence of the Internet, the western money worship, hedonism, and extreme individualism and other bad thoughts on college campuses spread and spread, seriously affected the college students' value orientation, polluted the pure campus culture. To strengthen the construction of school spirit culture, play a typical character exemplary and leading role and the university spirit construction. College students' ideological and political education work must be based on the actual, grasp the era characteristics, adhere to the socialist core values guide the construction of campus culture in colleges and universities, fully absorb all the favorable factors that is conducive to promoting the construction of harmonious campus culture, inherit and carry forward the excellent traditional culture of the Chinese nation, create conditions for the healthy growth of college students. (2) Actively carry out social practice activity. Carry out a variety of social practice activities, strengthen college students' understanding and the understanding of socialist core values and improve the practice of socialist core values consciousness which will help students understand the society. Through social practice to deepen college students' mastery of Marxist theory, to strengthen the understanding of socialist core values, enhance the identity of the common ideal of socialism and establish the social responsibility consciousness, collectivism idea. (3) Guide students to establish correct values of life. A person's values determine its behavior and attitude in life, to actively guide students to set up the common ideal of socialism, to cultivate patriotic spirit and innovative spirit, strive to practice the socialist concept of honor and disgrace. Universities should give full play to the important role of ideological and political theory, adhere to Marxist theory as a guide and fully carry out the socialist core values education. Education college students combine 
social value and individual value, on the basis of realizing social value realization of individual value, thus set up the correct values of life.

\section{CONCLUSIONS}

In this paper, we conduct in-depth research on the new and innovative pattern of college students' ideological and political education under the guidance and perspective of the core values theory. The essence of the ideological and political education determines for the traditional moral education in the process of their work attitude. Deepen the ideological and political education, must be to take the attitude of respect, study and draw lessons from traditional moral instruction. Only the traditional moral education as the root of the nation state, giving due respect, it can with the eye of history and reality in the future from the past multi-angle look at traditional moral education, system and research, clarify its historical context, to explore its contemporary value and significance for the traditional moral education and ideological and political education of contemporary university students. In the future, we will research more on the literature review to modify the current method.

\section{Acknowledgement}

This research is financially supported by the Guangxi higher education in the new century educational reform project key projects of 2011 (NO. 2011JGZ092). The project name is: the life education theory research and practice of college students hosted and finalized by Shuyun Ruan.

\section{References}

[1] Heng-Bing L I, Li B Q, Huang L. On the Core Position of Belief Education in the Ideological and Political Education for College Students[J]. Journal of Central South University of Forestry.

[2] Dan Y E. Innovation of the Ideological and Political Education of College Students under the Guidance of the Scientific Development Perspective[J]. Journal of Hubei Radio \& Television.

[3] Wang A, Division S A. On Interaction Mechanism Between College Ideological and Political Education and Mental Health Education from the Perspective of Collaborative Theory[J]. Journal of Huaihai Institute of Technology, 2013. 